\title{
A Life on the Hyphen-Bicultural Identity in Virgil Suarez's Going
} Under

\author{
Renran Zhang ${ }^{1} \&$ Guiyu Dai ${ }^{2}$ \\ ${ }^{1}$ Faculty of English Language and Culture, Guangdong University of Foreign Studies, Guangzhou, Guangdong \\ Province, China \\ Correspondence: Renran Zhang, Faculty of English Language and Culture, Guangdong University of Foreign \\ Studies, Guangzhou, Guangdong Province, China. Tel: 86-159-1992-2995. E-mail: renran_zhang@163.com
}

Received: September 20, 2019 Accepted: October 10, 2019 Online Published: October 29, 2019

doi:10.5539/hes.v9n4p162

URL: https://doi.org/10.5539/hes.v9n4p162

\begin{abstract}
This thesis is intended to delve into the one-and-a-half generation of Cuban-American's bicultural identity in Virgil Suarez's novel Going Under. Through an interpretation from the perspective of diaspora consciousness, this paper will identify how the main character constructs his individual identity through a network of usually competitive and incompatible elements like language, culture, religion, political ideologies and so on. Xavier Cuevas, the protagonist in this novel, maintains an unstable relationship with the American culture which he believes he has been wholly assimilated. The tension and anxiety lead him to "go under" and search for roots to return to the moment before exile.
\end{abstract}

Keywords: Going Under, Hyphenated Identity, One-and-a-half Generation, Cultural Identity

\section{Introduction to Virgil Suarez and Going Under}

Virgil Suarez is a Cuban-American poet and novelist and one of the leading writers in the Cuban-American community, known for his novels including Latin Jazz (1989) and Going Under (1996). Suarez has long been interested in and dedicated his work to the theme of exiled Cuban-American family in search of an American dream.

Xavier Cuevas, the overworked protagonist in the novel is a YUCA-young upwardly mobile Cuban American-living in Miami. But the possession of a car, a cellular phone and a modern home can't compensate for his parents' divorce, his own failing marriage and his declining health. His life crisis is further complicated by the fact that he can't identify with either American or Cuban culture, though he consciously believes that he has assimilated wholly to the American society. Paradoxically, he is embarrassed by his friend and business partner's heavy accents, but at the same time he despises the cold, American lifestyle of his blond, white-skinned, American wife's family. Symbolically, Cuevas is always stuck in the traffic jams just as he is stuck in the two cultures.

Xavier Cuevas's bicultural identity is unstable due to his innermost longing for going to his long-lost home, the irreplaceable and untouchable Cuba. Unable to acquire a hybrid identity through his cultural experiences, he formulates an ideal image of Cuba based on his childhood experience where he can take refuge. He may reside in the United States, but he doesn't live there. Cuba is his home where he can not only have his treasured memories and cultural identity, but also live a real life. Virgil Suarez puts Xavier Cuevas in an anxious position where his Cuban descent and American experience compete to win Cuevas's cultural identity. Unable to negotiate this confrontation, Xavier chooses to "go under" to find his roots where he can finally find peace.

\section{A Life on the Hyphen-Struggle of In-Betweenness}

\subsection{Perplexity in Between}

Ruben Rumbaut has labeled the "1.5" or "one-and-a-half" generation as "Children who were born abroad but are being educated and come of age in the United States form what may be called the "1.5" generation. These refugee youths must cope with two crisis-producing and identity-defining transition: (1) adolescence and the task of managing the transition from childhood to adulthood, and (2) acculturation and the task of managing the transition from one socio-cultural environment to another. The "first" generation of their parents, who are fully part of the "old" world, face only the latter; the "second" generation of children now being born and reared in the 
United States, who as such become fully part of the "new" world, will need to confront only the former. But members of the " 1.5 " generation form a distinctive cohort in that in many ways they are marginal to both the old and the new worlds, and are fully part of neither of them" (Rumbaut, 1991).

In this case, for Cuevas's parents and his children, the options are much more limited. Cuevas's father has no choice but to be Cuba. The long time of living and working in the United States seem to have little impact on his Cuban ways. After Cuevas's mental breakdown, his father takes him to a Santeria, namely a Cuban religious saint for a traditional way of healing and cure. Comparatively, his children who were born in America of a Cuban parent, are "American through and through" (Firmat, 1995). Although they belong to the so-called ABC generation (American-born Cubans), they are Cubans in their last name only. A better name for them would be CBA generation (Cuban-bred Americans). Though Xavier tries to impart his children Spanish, his elder son Eric "understood Spanish but refused to speak it" (Suarez, 1996). Xavier Cuevas belongs to the "1.5" generation, who constantly oscillates between Cuban culture and American culture, trying to locate a stable identity.

In the novel, Xavier Cuevas is always caught, both literally and metaphorically, in traffic. On the literal level, as an insurance salesman, he is trapped in his 240 GL Volvo, slowly managing his way from client to client and from home to office in order to sell them a promise of security and stability in the form of life insurance. Overwhelmed by his work, irritated when stuck in traffic, hastened to meet one after another appointment, and glued to his cell phone linking himself, his family and his work, Cuevas's life is in a breathless and suffocating tempo. Most of his time and life is spent on the road. On the symbolic level, Cuevas's experience in traffic mirrors his deepest feelings of being stuck between two cultures like language, eating habits, social customs and so on. Grown up in the United States, but born a descendent of Cuban parents, this YUCA (Young Urban Cuban-American) feels trapped between two cultures and countries.

\subsection{Name Confusion}

The readers may notice the name of the protagonist is Xavier, similar with but different from the usually common version of the almost same pronunciation "Javier". In the novel whenever Cuevas introduces himself to a new character, like the first time he meets his future father-in-law or any client, they always assume that his name "Xavier" is a Cuban-descent but Americanized version of "Javier". For example, "Eliosa, a client from way back when he started to sell insurances... always pronounced his name with a 'J' for Javier". "Cuevas", he introduced himself, "Xavier Cuevas." "Not Javier?" "No, with an X". Especially when Xavier meets his father-in-law whose daughter is a native American, for the first time,

"It's Javier, isn't it? Not Xavier. Like Mexico is Mejico,” Mr. Triste said.

"X-avier," Xavier said. (Suarez, 1996)

The constant repeating and reaffirmation of his name exacerbates Xavier's cultural discomfort and anxiety because the correction of his name of "X" instead of "J" often accompanies his explanation of the origins of his name and identity. On disclosing his hyphenated identity, Xavier is confronted by Mr. Triste's ominous prediction of his impending failing marriage: "You come from a different world than she does," he said, "and you're bound to have disagreements. Lots of them" (Suarez, 1996). Not unexpectedly, when Xavier's wife left him to New York, Mr. Triste said on telephone: "It wouldn't surprise me... You guys have had you troubles from the beginning. We've talked about this before. Oil and vinegar don't mix" (Suarez, 1996).

There is a need for Cuevas to justify himself, to give his confusing sense of self a definite letter instead of mixing "J" and "X". Recollecting his childhood, Cuevas realizes that the uneasy relationship with his cultural identity begins when he is still a child: "He fit in and so the children left him alone. That was the beginning of the transition in the unbalance of identity. More American, less Cuban. He was second generation. For all practical purposes, he got by, and that was the problem. This was his place. His country. He'd been here ninety-nine percent of his life; but the one percent made all the difference" (Suarez, 1996).

\subsection{Food Dichotomy}

In the novel Cuevas will eat arroz con pollo and platanos maduros fritos (both italicized words are Hispanic cuisines) with his mother in Hialeah, then go home to his blond, blue-eyed wife from Arizona and his children, "with their blond hair and fair skin, looked like her and nothing like him" (Suarez, 1996), and argue over whether dinner should be McDonald's or Chuck E. Cheese. For Cuevas, the conscious straddling of two cultures exhausts him. The Cuban-Americans, with a clear hyphen indicating biculturalism, through their exposure to both cultures, are in many ways "marginal to both the old and the new worlds, and are fully part of neither of them" (Firmat, 1995).

Trapped in - between cultures creates a third space, the kind of mental space that Gloria Anzaldua called a 
borderland, in which the dwellers, those with a hyphenated identity, develop a "tolerance for contradictions, a tolerance for ambiguity," they learn to "juggle cultures," operating "in a pluralistic mode," turning "ambivalence into something else" (Anzaldua, 2007). The hyphen that in a way connects the Cuban from the American, but seen from another perspective, it also a kind of separation.

For Cuevas, the hyphen means cultural alienation and psychic trauma. Conscious of the need to bridge the gap between la americanada (American)and lo cuhiche (Cuban), "he couldn't help but feel like an inadequate go-between: an equipped translator between two cultures"(Manso, 1999). He thinks to himself, "You busted your back, working hard to serve and understand one, la americanada" while protecting and respecting "lo cubiche, the source of his livelihood" (Suarez, 1996). Describing himself as a soldier fighting in the war, he has to fight for one side while still at the same time protecting the other.

\section{Going Under- Failure of In-Betweenness}

\subsection{The Vacillation between Ninety-nine Percent and One Percent}

Cuevas remembers his childhood as the beginning of his assimilation into American culture as well as the initial period of alienation from Cuban identity that will ultimately determine his sense of diasporic trauma. "At school no one ever made fun of him because he didn't look like an outsider. An immigrant. A wetback. He fit in and so the children left him alone. That was the beginning of the transition in the unbalance of identity. More American, less Cuban. He was second generation. For all practical purposes, he got by, and that was the problem" (Suarez, 1996).

The "difference" for Cuevas, "This was his place. His country. He'd been here ninety-nine percent of his life; but the one percent couldn't be ignored. Obviously, that one percent made all the difference" (Suarez, 1996). This one percent is critical in his alienation from his wife and children. Though he admits that "he found solace in her [Sarah] all-American good looks," his wife Sarah is the scapegoat for bearing two "blond-haired" children who "looked nothing like him" (Suarez, 1996). This, in Cuevas's view, is the erasure of his Cuban genes. Under the circumstance of his Cuban bloodline being contaminated and thinned, Cuevas left his family and seeks help through two ways: a return to his father's home in Miami and a spiritual cleansing administered by a Little Havana Santeria. Through these methods, Cuevas tries to re-establish purity and restores his Cuban identity.

\subsection{Awakening in the Santeria Ritual}

After a mental breakdown due to overwork and too much stress and anxiety, Cuevas explains to his assistant and his business partner, with intermittent gasps for air that he wants to be close to his father in Miami Beach. Because Cuevas's father and mother have been divorced for a long time and since then there has been a lack of communication between father and son, at first glance Cuevas's request seems strange. However, here Cuevas's father is actually symbolic of a Cuban origin that exists elsewhere.

Away from his English-speaking family, he feels lost. "Deep roots of confusion and angst had taken hold of Xavier's mind and soul...Something told him that he didn't belong" (Suarez, 1996). Fearing that his Cuban identity being submerged by American one, it is the sound of his father's Spanish that strengthens his firm confidence in retrieving his relationship with the island. "When he heard his father and Adolfo speaking in Spanish, the language of Xavier's infancy, vague memories bombarded Xavier. Memories of a simpler, happier time when he was a child, when his parents lived in the same house, when his roots were still connected." (Suarez, 1996).

In order to "inscribe himself within the space of the Cuban and to get in touch with his cultural soul and identity" (Manso, 1999), Cuevas's father suggests a ritual cleansing that will remove the impure elements interfering with his son's sense of Cuban disconnectedness. Here the healing power and help from the Santeria may signify the continued survival of Cuban cultural practices which haven't been contaminated by American culture and will win Cuevas's trust and favor.

During the cleansing ritual performed by the Santeria, Cuevas "told Caledonia [the Santeria] everything he could about his aspirations of one day making a lot of money in the insurance business, but yet all that had been undermined by a strong feeling of detachment and dislocation." Though Cuevas has hoped to merge Cubanness into his American identity, he is forced to offer a clear answer to the following question: "Are you Cuban or American?" (Suarez, 1996). Caledonia's question forces Cuevas to confront directly his own confusion and fear of a cultural loss and diasporic trauma as well as his marked "sense of emptiness" (Manso, 1999). Unable and impossible to choose both, or locate himself in biculturality, Cuevas is compelled to view his current ambivalent relationship to homeland and the decision whether to choose American or Cuban as an either-or dilemma. To completely accept one home is to turn down the other one. According to Caledonia, Cuevas needs to understand 
that to attain lo cubiche one essentially needs to purge la americanada.

During the ritual, the spirit guide gives a seemingly simple advice, "You have to go back to the beginning. You have to come in contact with your old self" (Suarez, 1996). Once the ritual is completed, Cuevas sets himself free from the afflicting position of constantly scurry to and fro from one culture to another. Now Cuevas regards his identity not as a negotiation between cultures any more, but as a return to his primary culture associated with geography and memories of childhood. For Cuevas, the term "Cuban-American" cannot exist, at least for him, because the term's two composing elements remain utterly irreconcilable in his mind.

\subsection{Seeking for and Returning to the Root}

Xavier, faced with his father-in-law's distrust of his daughter's inter-ethnic marriage with him, the emptiness he felt with material acquisition, and his blond, blue-eyed son's refusal to speak Spanish, Cuevas finally admits that even the assimilation course reaches $99 \%$, it is still far from enough. The missing percent is actually the mark of Cuevas's Cuban identity and the root cause of his difference from his family which cannot be obliterated or entirely subsumed, because, in his mind, his true cultural identity is in the end "carried in his blood" (Suarez, 1996). By then Xavier has been an onlooker rather than participant in Cuban culture. He follows American cultural routines that don't belong to him, which may be the origin of his sense of emptiness and dislocation. Urged to retrieve his real identity, the idea of return hovers in his head. Only in the Cuba of his childhood will Cuevas believe himself is a whole genetically, culturally, linguistically and psychologically.

The reconnection with his "old self" can only be accomplished "by getting in touch with the Cuban buried inside him, by going under and bringing to the surface the hidden part of his identity, his cultural soul" (Manso, 1999). Cuevas decides to return to Cuban ways of life, for example, the dancing, the music, and the food, in order to reestablish the kernel of Cuban life he feels he has alienated after participating in consumerism and assimilation of American culture. In a musical instrument store, Cuevas finds a conga, the traditional Cuban musical instrument, that he can play fluently. "Xavier felt the excitement in his blood. Perhaps this would make the difference. It was the sudden realization that something as easy as playing the congas could make him feel so good. Giddy with pleasure, Xavier paid for the instruments and took them to the office" (Suarez, 1996).

Cuevas believes that only through his pilgrimage to Cuba can he start the trauma-healing and identity-stabilizing of recovering the cultural and linguistic loss he has suffered in exile. The spirit guide and the haunting idea of returning to Cuba compel Cuevas to travel southward in hopes of reconnecting with the island. Leaving behind the car and the traffic, the long list of clients waiting, the blond-haired and white-skinned family, and the cellular phone, Cuevas pursues a course that will rewrite his identity which has confused him for such a long time. Heading to the Florida Keys, "without a map or a compass" (Suarez, 1996), he leaves behind the consumerism and assimilation that once directed his unsatisfactory and suffocating life: "past liquor stores, banks, fast-food restaurants, gift shops, tourist traps, sea-shell motels and dead-hour resorts. . . Xavier yearned for a way to be somewhere else. He drove on" (Suarez, 1996). But even if he can see Havana, there is no way he can reach Havana. Cuevas cannot complete the journey. The novel ends with the narrator plunging into the water and swimming "in the pursuit of the unattainable" (Suarez, 1996).

Literally going under, this may be interpreted as a suicide for he cannot actually go home. Moreover, in many Cuban-American artists' work, they depict 'the ocean as a place of possibility, tragedy and diasporic identity. Cuban artists on both sides of the Florida Straits have explored the sea as a traumatized region" (Lewthwaite, 2017). Once Cuevas asks himself "Why can't I be Cuban here? Because geography matters. Geography and climate matter. This is what I'm talking about. You've lost your way because you've become a bland mix of nothing but routines. Thoughtless, meaningless routines. This is the American way. You don't want to do this. Life here has no rhythm, only empty chores. Right?... So what's the answer? Go back... go back to where you belong, your rightful place in time. Our history, your history, is one of returning..." (Suarez, 1996). Determined that only Cuba can save him, he embarks on the search for an unattainable home that eventually kills him.

\section{Conclusion}

This paper mainly deals with the complexity of identity construction for the "one-and-a-half" generation who is a Cuban living in America. Virgil Suarez portrays in Going Under the complicated life of a young urban Cuban-American engaged in a search for both cultural and personal identity. The protagonist Xavier Cuevas has to find an outlet to mediate the diasporic trauma and put an end to the "strong feeling of detachment and dislocation" that has haunts him. (Suarez, 1996) For the author of the novel Virgil Suarez, the translation between two cultures is problematic; nostalgia is also questionable. Only by return can one find the inner peace. "One must go under and search between the multiple layers that structure one's cultural identity as a hyphenated American" (Manso, 1999). 


\section{Acknowledgement}

First and foremost, I would like to show my deepest gratitude to my supervisor, Pro. Guiyu Dai, a respectable and responsible scholar, who has provided me with valuable guidance in every stage of the writing of this thesis. Without her enlightening instruction, impressive kindness and patience, I could not have completed my thesis. Her keen and vigorous academic observation enlightens me not only in this thesis but also in my life and my future study.

I shall extend my thanks to thank all my teachers in the Faculty of English Language and Culture in Guangdong University of Foreign Studies who have helped me to develop essential academic competence. My sincere appreciation also goes to my parents for their encouragement and support in my pursuit of my doctor degree.

\section{References}

Anzaldua, G. (2007). Borderlands/La Frontera (3rd ed.). San Francisco: Aunt Lute Books.

Firmat, G. P. (1995). Next Year in Cuba-A Cubano's Coming-of-Age in America. New York: Anchor Books.

Lewthwaite, S. (2017). Seeing in the Dark: The Aesthetics of Disappearance and Remembrance in the Work of Alberto Rey. Journal of American Studies, 51(2), 591-621. https://doi.org/10.1017/S0021875816000979

Manso, L. A. (1999). Going Under and Spared Angola: Memories from a Cuban-American Childhood-A Contrapunteo on Cultural Identity. Bilingual Review, 24(3), 295-298.

Rumbaut, R. G. (1991). The Agony of Exile: A Study of the Migration and Adaptation of Indochinese Refugee Adults and Children. In Frederick L. Ahearn Jr. and Jean L. Athey (Eds.), Refugee Children: Theory, Research, and Services. Baltimore: Johns Hopkins University Press.

Suarez, V. (1996). Going Under. Huston: Arte Publico Press.

\section{Copyrights}

Copyright for this article is retained by the author(s), with first publication rights granted to the journal.

This is an open-access article distributed under the terms and conditions of the Creative Commons Attribution license (http://creativecommons.org/licenses/by/4.0/). 